\title{
Prosodic Reduplication in Yorùbá
}

\author{
Taiwo O. Ehineni \\ Indiana University, USA
}

\begin{abstract}
Yoruba is considered by Haspelmath \& Sims (2010) to be an analytic language with very little affixation. However, they seem to ignore the widespread use of reduplication found in the language. The phenomenon of reduplication has been examined in Yorùbá as productive process of word formation (Pulleyblank 2009). In this view, this paper examines the prosodic template in Yorùbá focusing specifically on Yorùbá adverbial reduplicated forms and other forms. Previous studies on prosodic analysis of reduplication in Yoruba have focused on agentive forms, any-forms, distributive and gerundive forms (Orie \& Pulleyblank 2002, Pulleyblank 2009). However, no previous studies focused on the adverbial where I have observed some reduplicative patterns. In this paper, data on adverbials are examined and compared with other reduplicative
\end{abstract}

\footnotetext{
Taiwo O. Ehineni

Department of Linguistics, Indiana University, Bloomington, IN 47405

Email: tehineni@indiana.edu
}

Received 3 August, 2017; Revised 24 August, 2017; Accepted 5 September, 2017

Copyright (C 2017 Language Research Institute, Sejong University

Journal of Universal Language is an Open Access Journal. All articles are distributed online under the terms of the Creative Commons Attribution Non-Commercial Licence (http://creativecommons.org/licenses/by-nc/3.0) which permits unrestricted non-commercial use, distribution, and reproduction in any medium, provided the original work is properly cited. 
forms. The discussion, which is framed within the optimalitytheoretic framework, reveals that the base is required to be bimoraic (foot or syllable) for reduplication to take place since monomoraic forms do not reduplicate. I argue that while the basic constraint hierarchy for Yoruba prosodic reduplication can be presented as IDENT BR, RED = STEM, NO HIATUS $>$ MAX-IO, other constraints ranking (as discussed in the paper) may be triggered by other processes occurring within the reduplication.

Keywords: reduplication, constraints, optimality, Yoruba, prosodic template

\section{Introduction}

This paper examines the nature of prosodic reduplication in Yorùbá focusing on the derivation of adverbial, agentive nominal, and "any" forms. I observe generally that these three forms most times require some prosodic shape for reduplication to occur. The first case deals with deriving the adverbial, specifically, degree adverbs from normal adverbs. Here, the reduplicant has to be bimoraic such that when the condition is not met, there is no reduplication. For instance, in examples where the base is monomoraic, no reduplication is realized. In the second case which has to do with deriving the agentive, the base may be bimoraic or multimoraic for reduplication to take place. The third case deals with infixing reduplication where the morpheme ' $k 1$ ' is infixed between the base and the reduplicant which must not be monomoraic. This only occurs when the base has a high front vowel as the initial phoneme. Thus, in this paper, I present and discuss some Yorùbá data to account for this nature of reduplication. Based on the analysis of 
the data, I claim that the reduplicant is required to have a prosodic shape of that is more than one mora such that when the base is monomoraic, reduplication is impossible. Also, while Haspelmath \& Sims (2010) claim that Yorùbá is an analytic language in terms of morphology, I note that it has rich morphological reduplication which can be argued to be a form of affixation where the reduplicant is viewed as being affixed to the base.

It is worth noting that the issue of reduplication has been widely discussed in other languages. Abakah (2015) discusses morphological, segmental, and tonal processes related to the reduplicative construction in Akan. Drawing examples from verbs, adjectives, and nouns, he indicates that words belonging to the same class behave tonally the same. Thus, segmental melodies of the base are at times copied during reduplication. Furthermore, Tak (2007) examines how three languages including Chichewa, Sesotho, and Agta satisfy the three cross-linguistic tendencies in reduplication such as Shape Invariance, Unmarkedness, and Identity. However, this study examines reduplication in Yoruba, from a prosodic perspective where it is argued that prosodic templates influence patterns of reduplication.

\section{A Short Background on Yorùbá and Reduplication}

Yorùbá is a Benue-Congo language spoken in Nigeria and other parts of West Africa. It has a CV syllable structure and has three constrastive tones: low, mid, high. These tones are used to indicate lexical and semantic contrast in the language. i.e., bi (ask), bí (give birth), bì (throw up). A crucial thing to note for this data is vowel hiatus which occurs in Yorùbá morphology. Vowel hiatus deals with the prohibition of a sequence of vowels across a syllable boundary. 
For instance, the verb wokọ ${ }^{1}$ 'drive car' (< wa okò 'drive a car'). Here, the mid vowel $a$ is deleted in process of combining the $\mathrm{V}+\mathrm{N}$. The deletion here occurs to prevent two different vowels from cooccurring which is not allowed in the language. Reduplication in Yorùbá could be total or full, where all segments are completely copied, for instance in agentives which are often derived by exactly reduplicating a verb + noun form as in examples such as woléwolé 'house inspector' (< wolé 'inspect house'), pejapeja 'fisherman' (< peja 'kill fish'). Pulleyblank (2009) suggests two approaches of analyzing this form of reduplication, one is to look at a part as the base and the other as reduplicant while the other is to analyze both parts as a form of compounding (following Inkelas \& Zoll 2005, Hyman, Inkelas \& Sibanda 2009). However, the two approaches have implications for different semantic interpretation in Yorùbá. Furthermore, reduplication in Yorùbá can also be partial where only the initial consonant of a segment is reduplicated in the realized form. It could also include a class of reduplicative cases like word linkers between two identical noun components which often involves the infix /kí/ within the reduplicated form (Awoyale 1991).

\section{Data Description}

In this section, I describe the data for analysis in the paper. The first set deals with forming the adverbial, the second set deals with

\footnotetext{
1 Complex verbs such as wọkọ are very common in the language. Some others include șíṣe (< șe iṣẹe ‘do work'), sárẹe (< sá erẹe 'run race'), raṣọ (< ra aṣọ 'buy cloth'), etc. The general process here is vowel elision. Vowel elision occurs here to resolve vowel hiatus. See Orie \& Pulleyblank 2002 on detailed discussion of vowel elision in Yoruba.
} 
forming the agentive nominal and the third relates to the formation of 'any' constructions. Consider the first data set in Table 1 below that shows the adverbial formation:

Table 1. The Formation of Adverbials in Yoruba by Reduplication

\begin{tabular}{|c|c|c|c|c|}
\hline & Verb & Gloss & Adverbial & Gloss \\
\hline \hline 1. & fìrí & 'in a haste' & fîrífírí & 'hastily' \\
\hline 2. & kíá & 'quick' & kíákíá & 'quickly' \\
\hline 3. & gidi & 'much' & gidigidi & 'very much' \\
\hline 4. & tipá & 'by force' & tipátipá & 'forcefully' \\
\hline 5. & tóní & 'spotless' & tónítóní & 'spotlessly' \\
\hline 6. & ńlá & 'large' & ńlánlá & 'largely' \\
\hline 7. & tayọ̀ & 'with joy' & tayọ̀tayọ̀ & 'joyfully' \\
\hline 8. & díẹ̀ & 'little' & dịệdịẹ̀ & 'very little' \\
\hline 9. & jù & 'more' & *jùjù & - \\
\hline 10. & gã & 'much' & *gãgã & - \\
\hline 11. & púpọ̀ & 'much' & púpọpúpọ̀ & 'very much' \\
\hline
\end{tabular}

This data set refers to the formation of (degree) adverbials from adverbs. In Yorùba, adverbs can have different prosodic structures but not all adverbs reduplicate in forming adverbials especially when the base is lesser than the template required by the reduplicant. Consider the second data set in Table 2 below that show the agentive formation:

Table 2. The Formation of the Agentive in Yoruba by Reduplication

\begin{tabular}{|c|c|c|c|c|}
\hline & Verb & Gloss & Agentive & Gloss \\
\hline \hline 1. & paná & 'quench (fire)' & panápaná & 'firefighter' \\
\hline 2. & wolé & 'inspect (house)' & woléwolé & 'inspector' \\
\hline
\end{tabular}




\begin{tabular}{|c|c|c|c|c|}
\hline 3. & yọyín & 'remove (teeth)' & yọínyọín & 'dentist' \\
\hline 4. & wáșẹ́ & 'seek (job)' & wáșẹ́wáṣẹ́ & 'job seeker' \\
\hline 5. & gbálẹ̀ & 'sweep (floor)' & gbálẹ̀gbálẹ̀ & 'floor sweeper' \\
\hline 6. & gbá & 'sweep' & *gbágbá & - \\
\hline 7. & wo & 'inspect' & *wowo & - \\
\hline 8. & dírọ́bà & 'repair (plastic)' & dírọ́bàdírọ́bà & 'plastic repairer' \\
\hline 9. & dí & 'repair' & *dídí & - \\
\hline 10. & fọgọ́tà & 'wash gutter' & fọgọ́tàfọgọ́tà & 'gutter washer' \\
\hline 11. & fọ & 'wash' & *oọfọ & - \\
\hline
\end{tabular}

The second data set in Table 2 deals with how agentive nominals are formed from complex verbs through reduplication. While verbs in Yorùbá have different prosodic structures, not all verbs can reduplicate to form nominals. The reduplicant may be bimoraic or trimoraic. Thus, when the base is monomoraic, no reduplication occurs. Consider the first data in Table 3 below that show the derivation of any forms:

Table 3. The Formation of 'Any' Constructions in Yoruba by Reduplication

\begin{tabular}{|c|c|c|c|c|}
\hline & Root & Underlying form & Derived form & Gloss \\
\hline 1. & ilé & ilé-kí-ilé & ilékílé & 'any house' \\
\hline 2. & așọ & așọ-kí-aṣọ & așọkáșọ & 'any cloth' \\
\hline 3. & ọmọ & ọmọ-kí-ọmọ & ọmọkọ́mọ & 'any child' \\
\hline 4. & ìwé & ìwé-kí-ìwé & ìwékíwè & 'any book' \\
\hline 5. & bàbá & bàbá-kí-bàbá & bàbákíbàbá & 'any father' \\
\hline 6. & màmá & màmá-kí-màmá & màmákímàmá & 'any mother' \\
\hline 7. & ibi & ibi-kí-ibi & ibikíbi & 'any place' \\
\hline 8. & òșìșẹ́ & òṣișẹékí-òșìsẹe & òșisṣẹ́kóṣìșẹé & 'any worker' \\
\hline
\end{tabular}




\begin{tabular}{|c|c|c|c|c|}
\hline 9. & awakọ̀ & awakọ̀-kí-awakọ & awakọ̀káwakọ & 'any driver' \\
\hline 10. & alágídí & alágídí-kí-alágídí & alágídíkálágídí & $\begin{array}{c}\text { 'any stubborn } \\
\text { person' }\end{array}$ \\
\hline 11. & ìgbé & ìgbé-kí-ìgbé & ìgbékúgbé & $\begin{array}{c}\text { 'any thing } \\
\text { carried' }\end{array}$ \\
\hline 12. & ìgbà & ìgbà-kí-ìgbà & ìgbàkúgbà & 'any time' \\
\hline
\end{tabular}

The third data set relates to the derivation of 'any' forms from nouns. It deals with infixing reduplication where the morpheme ' $k 1$ '' is infixed between the base and the reduplicant which must not be monomoraic. This only occurs when the base has a high front vowel as the initial phoneme. In this case, if the base of the word begins with a high front vowel /í/ then the front vowel in /kí/ deletes and the high tone is transferred to initial vowel of the reduplicant. Also, vowel hiatus occurs in Yorùbá making a high front vowel /i/ deletes before another vowel. Furthermore, the last three examples $(\mathrm{k}, 1, \mathrm{~m})$ of the data in Table 3 deals with a case of fusion. It seems that the two high front vowels coming together at syllable boundary are fused into a new one $/ \mathrm{u} /$ (the tone of the first vowel in the sequence is still preserved by transfer).

I now proceed to provide more detailed analysis of the data sets in terms of the nature of prosodic reduplication in the language in the next section.

\section{Prosodic Constraints in Yoruba Reduplication}

In all the three data sets, the reduplicant has a prosodic shape/template which is either bimoraic or more. The mora is the 
lowest prosodic unit in the prosodic hierachy as in: prosodic word > foot > syllable > mora (Kager 2004). It is observed that when the base is less than a bimoraic foot, reduplication does not occur. Thus, there is an overriding constraint in terms of reduplication: *Monomoraic base (No monomoraic base). This simply implies that the base has to be more than a mora. This constraint is a prosodic constraint on the base that influences reduplication in Yorùbá.

In the first data set dealing with forming adverbials, the reduplicant has to be exactly a bimoraic foot or syllable for reduplication to take place. However, in Yorùbá, there are forms with a base that is monomoraic but no reduplication takes place because the prosodic requirement of bimoraicity is not met. Hence, examples such 'jù' and 'gan' do not undergo any form of reduplication because the base is monomoraic.

The second data set which deals with the derivation of agentive nominals, the reduplicant could be bimoraic or multimoraic but not less. Thus, from the data, 'paná' becomes panápapá, 'wolé' becomes woléwolé, 'gbálệ' becomes gbálẹgbálè etc. However, 'gbá' does not become *gbágbá nor 'fọ̀' become *fọfọ̆. Thus, there is no case of reduplication in monomoraic forms.

The third data set is a case of "infixing reduplication" - what is meant here is that it deals with a kind of reduplication where an infix occurs between the reduplicant and the base. First, just like the second data, a template that is at least bimoraic is required in the reduplicant. Also, the infix ' $\mathrm{ki}$ ' is inserted between the base and the reduplicant, and the front vowel is deleted to resolve vowel hiatus (see section 2 for more discussion on this). However, while the position of the reduplicant in terms of its attachment to the base may be difficult to ascertain, this paper assumes that the reduplicant is a kind of affix that is prefixed to the base. This idea of prefixing 
reduplication is assumed based on the fact that Yorùbá is a prefixing language. It actually has a number of prefixes which has been grouped into two different classes (Owolabi 1995, Taiwo 2013). Furthermore, this paper observes that the fusion of vowel sequences as seen in last three examples in Table 3, section 3, is another way through which vowel hiatus resolution is carried out in Yorùbá. While Orie \& Pulleyblank (2002) in their study identified two strategies including vowel deletion and assimilation, this study reveals a case of fusion where $\mathrm{V}_{1}$ and $\mathrm{V}_{2}$ become a back vowel $/ \mathrm{u} /$. This occurs in vowel sequences involving the high front vowel /i/.

\section{Optimality-Theoretical (OT) Analysis}

In this section, I provide an OT analysis of the different sets of data described in the previous sections. While certain constraints have been observed to influence the reduplicative patterns, the OT framework (McCarthy \& Prince 1995) is used to identify significant prosodic constraints governing the forms of reduplication. Thus, a number of relevant constraints are presented and discussed below:

- IDENT BR - assign a constraint violation for a feature in the base not present in the reduplicant.

- $\mathrm{RED}=\mathrm{STEM}\left(\right.$ where STEM $\left.>\sigma_{\mu}\right)-$ assign a constraint violation when the reduplicant does not equal the stem.

- IO FAITHFULNESS - assign a constraint violation when the input does not match the output.

- $\mathrm{STEM}>\sigma_{\mu}-$ assign a constraint violation when the stem is not greater than a mora. 
- NO HIATUS - assign a constraint violation for a sequence of vowels across syllable boundary.

- MAX-IO - assign a constraint violation for a feature in the input not present in the output.

- UNIFORMITY - assign a constraint violation when one element in the output has multiple correspondents in the output.

- IDENT-IO (high) - assign a constraint violation when the vowel feature (high) in the input has no correspondent in the output.

- ReAlize MoRPheme (i.e., MPARSE) - assign a constraint violation when a morpheme is not parsed into morphological constituents.

I proceed to analyze the first data set on adverbial reduplication (provided in Table 1, section 3 of this paper) in the following tableaux:

(1) /tipá/ $\rightarrow$ [tipátipá] 'forcefully'

\begin{tabular}{|rl||c|c|}
\hline \multicolumn{1}{|c|}{$/$ RED + tipá/ } & IDENT BR & RED = STEM \\
\hline \hline a. & ti-tipá & $*$ & $*$ \\
\hline \multirow{2}{*}{ b. $\quad$ tipá-tipá } & & \\
\hline
\end{tabular}

As seen in the above tableau, candidate (a) 'ti-tipa' is ruled out by violating both IDENT BR and RED $=$ STEM. The RED does not share identity with the base, violating IDENT BR and it is monomoraic violating RED = STEM. However, candidate (b), tipá-tipá, wins since it does not violate any constraints. There is really no constraint ranking here with respect to the winning candidate because if the ranking is reversed, the right candidate still emerges as shown below: 
(2) /tipá/ $\rightarrow$ [tipátipá] 'forcefully'

\begin{tabular}{|rl||c|c|}
\hline \multicolumn{1}{|c|}{$/$ RED + tipál } & RED = STEM & IDENT BR \\
\hline \hline a. & ti-tipá & $*$ & $*$ \\
\hline$\varpi$ b. & tipá-tipá & & \\
\hline
\end{tabular}

From the above reversed ranking, tipá-tipá still wins while other forms tibá-tipá, ti-tipá are dismissed. Thus, we include other candidates, to confirm our constraints analysis and our observation above that there is no ranking argument.

(3) /tipá/ $\rightarrow$ [tipátipá] 'forcefully'

\begin{tabular}{|rl||c|c|}
\hline \multicolumn{1}{|c|}{$/$ RED + tipá/ } & IDENT BR & RED = STEM \\
\hline \hline a. & tibá-tipá & $* !$ & \\
\hline$\varpi$ b. & tipá-tipá & & \\
\hline
\end{tabular}

The first candidate (3a) tibá-tipá does not violate RED = STEM since it is bimoraic but it violates IDENT BR because it does not exactly reflect the base features and is therefore ruled out by IDENT BR. The second candidate ( $3 \mathrm{~b}$ ) wins by not violating any constraint. Also, like the previous example, there is no ranking argument since reversing the ranking does not affect the right output in the analysis. A more clear analysis of these candidates and constraints is given below in (4)

(4) /tipál $\rightarrow$ [tipátipá] 'forcefully'

\begin{tabular}{|rl||c|c|}
\hline \multicolumn{2}{|c||}{ /RED + tipá/ } & IDENT BR & RED = STEM \\
\hline \hline a. & ti-tipá & $*$ & \\
\hline b. & tibá-tipá & $*$ & \\
\hline c. & tipá-tipá & & \\
\hline d. & tip-tipá & $*$ & $*$ \\
\hline
\end{tabular}


The last example (4d), tip-tipá violates $\mathrm{RED}=$ STEM since the RED is monomoraic because in Yoruba, obstruents are not moraic. ${ }^{2}$ Crucially, what I have shown above is that there is no ranking argument between constraints IDENT BR and RED $=$ STEM in terms of producing the optimal candidate in adverbial reduplication.

In the following analyses, I discuss examples (j) and (k) in the first data set in Table 1. These examples relate to cases where reduplication does not apply within the adverbial group in Yoruba, analysis of these cases of non-reduplication is presented in the tableaux (5) below.

(5) /jù/ $\rightarrow$ [jù] 'more'

\begin{tabular}{|rl||c|c|c|}
\hline & $/$ RED + jù/ & IO FAITH & STEM $>\sigma_{\mu}$ & REALIZE MORPHEME \\
\hline \hline a. & jùujùu & $* !$ & & \\
\hline b. & jùjù & & $* !$ & \\
\hline$\sigma^{\circ}$ c. & $/$ RED + jù/ & & & $*$ \\
\hline
\end{tabular}

IO FAITH, STEM $>\sigma_{\mu}>>$ REALIZE MORPHEME

The candidate (5a) is ruled out by IO FAITH though it satisfies STEM $>\sigma_{\mu}$ and REALIZE MORPHEME, while candidate (5b) is ruled out by STEM $>\sigma_{\mu}$ since it is monomoraic though it satisfies IO FAITH and REALIZE MORPHEME. The third candidate (5c) wins by not violating any of the high ranked constraints - IO FAITH and STEM > $\sigma_{\mu}$. Thus, the null candidate (5c) is optimal since all its competitors violate undominated constraints. However, there is a critical constraint ranking here: IO FAITH, STEM > $\sigma_{\mu} \gg$ REALIZE MORPHEME. In other words, REALIZE MORPHEME has to be low ranked to produce the right candidate. The analysis here relates to the

2 In Yoruba, nasal consonants in examples such as ńlá, ńlo are moraic. Thus, these examples are bimoraic and they can reduplicate as we find in data set in Table 1 , section 3 . 
emergence of the null candidate as optimal in OT discussed in Kager (2004: 401-403).

In the following sections, I examine the second issue in the analysis of Yoruba reduplication which deals with agentive formation. Here, complex verbs reduplicate to form nominal agents. Previous constraints identified in Table 1, section 3 are used to analyze the second data set:

(6) /dírọ́bà/ $\rightarrow$ [dírọ́bàdírọ́bà] 'plastic repairer'

\begin{tabular}{|c|c|c|c|}
\hline & /RED + dírọ́bà/ & IDENT BR & RED = STEM \\
\hline 电. & dírọ́bà-dírọ́bà & & \\
\hline b. & dírọ́-dírọ́bà & * & \\
\hline c. & dí-dírọ́bà & * & $*$ \\
\hline
\end{tabular}

As shown in (6), candidate (6a) díróbà-dírọbà does not violate both IDENT BR and RED = STEM, candidate $(6 \mathrm{~b})$ dírópà-díróbà violates only IDENT BR while candidate (6c) dí-dírọ́bà violates both IDENT BR and RED = STEM. The second candidate $(6 \mathrm{~b})$ díró -díróbà does not violate RED = STEM since the RED is bimoraic, which is greater than a mora, as required by the stem, but it violates IDENT BR because the RED is not identical to the base. On the other hand, candidate (6c) dí-díróbà violates RED = STEM since the RED is monomoraic which is lesser than the stem. This candidate also violates IDENT BR because the RED is not identical to the base. Consequently, candidate (6a) díróbà-díróbà emerges as the winning candidate. Also, there are no critical constraints ranking argument here. The losing candidates are all harmonically bound. Thus, the same constraints used for the analysis of adverbial reduplication also apply to the agentive formation.

The last data set on reduplication, presented in Table 3, deals with derivation of any forms in Yorùbá. This data involve not only 
reduplication but the infixing of an affix between the base and the reduplicant. For this analysis, the constraints NO HIATUS and MAXIO are used.

(7) /ilé/ $\rightarrow$ [ilé-kí-ilé] 'any house'

\begin{tabular}{|cl||c|c|}
\hline \multicolumn{2}{|c|}{ /RED + kí + STEM/ } & NO HIATUS & MAX-IO \\
\hline \hline a. $\quad$ ilé.kí.ilé & $* !$ & \\
\hline${ }^{\odot}$ b. $\quad$ ilé.kí.lé & & $*$ \\
\hline
\end{tabular}

NO HIATUS >> MAX-IO

In the above tableau (7), there is a ranking argument between No HIATUS and MAX-IO in terms of realizing the right output for this form of reduplication. Candidate (7a) satisfies MAX IO, but it is ruled out by NO HIATUS which is high ranked while the second candidate (7b) wins by not violating NO HIATUS. This constitutes a ranking argument since if the ranking of constraints is reversed, the wrong candidate will emerge as winner. This ranking especially deals with hiatus resolution involved in the process of reduplication. Here, the winning candidate has to also respect NO HIATUS for this kind of reduplication. Having established a critical ranking between No HIATUS and MAX-IO, I include the previous constraints considering other candidates:

(8) /ilé/ $\rightarrow$ [ilé-kí-ilé] 'any house'

\begin{tabular}{|c|c|c|c|c|}
\hline /RED + kí + STEM/ & IDENT BR & $\mathrm{RED}=\mathrm{STEM}$ & NO HIATUS & MAX-IO \\
\hline a. $\quad$ ilé.kí.ilé & & & $* !$ & \\
\hline ilé.k.ílé & & & & * \\
\hline lé.kí.ilé & $*$ & * & * & $*$ \\
\hline d. lé.kí.lé & $*$ & $*$ & & ** \\
\hline
\end{tabular}

IDENT BR, RED = STEM, NO HIATUS >> MAX-IO 
From the above tableau (8), the faithful candidate ilé.kí.ilé does not violate MAX-IO, but it is ruled out by NO HIATUS which is high ranked. Also, other candidates (c, d) supplied by GEN are ruled out by violating more constraints. Candidate (c) lé.kí.ilé violates IDENT BR since the RED is not identical with the base. It violates RED = STEM because the RED is monomoraic, lesser than the STEM requirement (since STEM $>\sigma_{\mu}$ ). It also violates NO HIATUS since there is vowel sequence across syllable boundary and MAX-IO, by deletion of the high vowel in the RED. The other candidate (d) lé.kílé similarly violates IDENT BR, RED $=$ STEM, and MAX-IO. It actually violates MAX-IO twice as a result of the deletion of the high front vowel both in the base and in the reduplicant. However, it does not violate No HiATUS. The candidate (b) ilé.k.ílé wins since it violates only MAX-IO which is lower ranked in our constraint ranking analysis. Thus, it is the most harmonic candidate in terms of the constraints. Basically, what we see is that the winning candidate is determined by the critical ranking of NO HIATUS and MAX-IO. It is this ranking that produces the optimal candidate ilé.k.ilé instead of the faithful candidate ilé.kí.ilé as winning candidate. Also, the overall ranking of constraints for reduplication, including all 3 forms, so far :

(9) IDENT BR, RED = STEM, NO HIATUS $>>$ MAX-IO

However, in the data set 3 (Table 3 in section 3), I also notice examples (k) and (1) - ighékúgbé and ìgbàkúgbà, in the 'any' form reduplication examples. I will analyze the process of reduplication in these two examples, using other constraints to account for the phonological process involved. More relevantly, I intend to contribute to recent studies on hiatus resolution strategies in Yorùbá (Orie \& Pulleyblank 2002), but in the context of reduplication. These 
examples (k) and (l) in the third data set are analyzed in the following section, especially in terms of the issue of hiatus resolution in reduplication

\section{Hiatus Resolution in Yorùbá and the Case of Reduplication}

Hiatus resolution has been identified as a major process in Yorùbá (Awoyale 1985, Akinlabi \& Oyebade 1987, Pulleyblank 1988, Ola 1991) where a sequence of vowels is prohibited across a syllable boundary. In a recent treatment of hiatus resolution in Yoruba (Orie \& Pulleyblank 2002), the authors identified two basic strategies of hiatus resolution in Yoruba based on previous literature (including ones already cited above). They identified deletion and assimilation as the major strategies, although they claim that deletion has been the most widely attested strategy for vowel hiatus: "a large literature on vowel sequences in Yoruba (Niger-Congo) has shown that deletion is a widely attested strategy for hiatus resolution in that language" (ibid: 101). Essentially, they draw new data from the language to analyze how not only deletion but assimilation operates in hiatus resolution in Yoruba. Thus, they focus on these two strategies - deletion and assimilation, in their OT analysis of hiatus resolution in Yoruba.

However, this study observes, from examples from the language which especially deals with cases of reduplication, that hiatus may be resolved by another strategy - fusion. I see fusion as a situation in which two diferent vowels combine into a different form. That is, $\mathrm{V}_{1}$ and $V_{2}$ in a vowel sequence across syllable boundary becomes $V_{3}$. The $V_{3}$ is often a different vowel from the two vowels co-occuring in 
the sequence. This deals with the fusion of [i] to [u] before velars in a hiatus environment. While it is difficult to find examples in some forms in Yoruba, especially the verbal examples largely examined in Orie \& Pulleyblank (2002), I draw examples from new data on reduplication forms. Thus, I therefore devote this section to analyze the last two examples in our third data set (ìgbékúgbé and ìgbàkúgbà). I include other constraints to account for not only the reduplication process but crucially the fusion process of resolving hiatus.

Fusion is proposed to violate a special faithfuness constraint that other operations do not necessarily violate - UNIFORMITY (McCarthy \& Prince 1995). For this analysis, I use UNIFORMITY and other constraints - NO HIATUS, MAX-IO IDENT (high), IDENT BR. I analyze both the faithful and optimal candidate in (10) below.

(10) /ìgbé.kí.ìgbé/ $\rightarrow$ [ìgbé.kú.gbé] 'anything carried'

\begin{tabular}{|r||c|c|c|}
\hline /RED + kí + STEM/ & NO HIATUS & UNIFORMITY & IDENT BR \\
\hline \hline a. ìgbé.kí.ìgbé & $* !$ & & \\
\hline b. ìgbé.kú.gbé & & $*$ & $*$ \\
\hline
\end{tabular}

NO HIATUS >> UNIFORMITY, IDENT BR

From the above tableau, the faithful candidate does not violate UNIFORMITY since there is no change in the output but it violates No HIATUS, which is high ranked, by having a sequence of vowels across syllable boundary. The other candidate igbé.kú.gbé violates UNIFORMITY since a different sound is realized in the output, and IDENT BR since the RED is not identical to the base, but it satisfies high ranked NO HIATUS. Thus, there is a critical ranking of constraints here: NO HIATUS >> UNIFORMITY, IDENT BR. In other words, UNIFORMITY and IDENT BR have to be low ranked to produce the optimal candidate. That is, the ranking of NO HIATUS over UNIFORMITY and IDENT BR rules out the faithful candidate. Using 
GEN, I consider another potential candidate ìgbé.kí.gbé which will satisfy high ranked NO HIATUS but may not be optimal.

(11) /ìgbé.kí.ìgbé/ $\rightarrow$ [ìgbé.kú.gbé] 'anything carried'

\begin{tabular}{|c||l|l|l|l|l|}
\hline$/$ RED + kí + STEM/ & $\begin{array}{l}\text { NO } \\
\text { HIATUS }\end{array}$ & $\begin{array}{l}\text { MAX- } \\
\text { IO }\end{array}$ & $\begin{array}{l}\text { IDENT } \\
\text { (high) }\end{array}$ & UNIFORMITY & $\begin{array}{l}\text { IDENT } \\
\text { BR }\end{array}$ \\
\hline \hline a. ìgbé.kí.ìgbé & $* !$ & & & & \\
\hline b. ìgbé.kí.gbé & & $* !$ & & & $*$ \\
\hline *c. ìgbé.kú.gbé & & & & $*$ & $*$ \\
\hline d. ìgbé.ké.gbé & & & $* !$ & $*$ & $*$ \\
\hline
\end{tabular}

NO HIATUS, MAX-IO >> IDENT (high), UNIFORMITY, IDENT BR

As seen in the above tableau (11), candidate (a), igbé.ki.gbé is ruled out by MAX-IO but not candidate (b). The second candidate is an example of fusion not deletion. Note that in deletion strategies of resolving hiatus (Orie \& Pulleyblank 2002), MAX-IO will be lower ranked, as also shown in previous sections (see tableaux $7 \& 8$ ). However, in fusion strategies of resolving hiatus in Yoruba, not addressed by Orie \& Pulleyblank (2002), UNIFORMITY will be lower ranked. I therefore provide a fuller analysis of constraints on fusion strategy of resolving hiatus in reduplication, including an additional potential candidate in (12).

(12) /îgbé.kí.ìgbé/ $\rightarrow$ [ìgbé.kú.gbé] 'anything carried'

\begin{tabular}{|c|c|c|c|c|c|}
\hline /RED + kí + STEM/ & $\begin{array}{l}\text { No } \\
\text { HIATUS }\end{array}$ & $\begin{array}{l}\text { MAX- } \\
\text { IO }\end{array}$ & $\begin{array}{l}\text { IDENT } \\
\text { (high) }\end{array}$ & UNIFORMITY & $\begin{array}{l}\text { IDENT } \\
\text { BR }\end{array}$ \\
\hline a. ìgbé.kí.ìgbé & $* !$ & & & & \\
\hline b. ìgbé.kí.gbé & & $* !$ & & & * \\
\hline F c. ìgbé.kú.gbé & & & & $*$ & $*$ \\
\hline d. ìgbé.ké.gbé & & & $* !$ & $*$ & $*$ \\
\hline
\end{tabular}

NO HIATUS, MAX-IO >> IDENT (high), UNIFORMITY, IDENT BR 
What I have done so far is to provide the analysis of fusion as a vowel hiatus strategy in Yoruba, especially in reduplication, different from deletion and assimilation identified by Orie \& Pulleyblank (2002). Essentially, the ranking of other constraints over UNIFORMITY and IDENT BR is crucial in producing the optimal candidate.

\section{Conclusion}

First, this paper has examined the nature of reduplication especially in adverbials, agentive and any formations in Yoruba within the framework of Optimality Theory and argues that these reduplication forms are influenced by prosodic constraints where the reduplicant requires a prosodic shape or pattern that is at least bimoraic for reduplication to occur. In other words, monomoraic forms block reduplication. It is observed that while there is no ranking argument between constraints in reduplication dealing with adverbial and agentive formations, there is a ranking argument between constraints in reduplication dealing the any forms which include both cases of reduplication and infixation.

Second, I claim, from the examples on reduplication, that fusion may be another way of resolving vowel hiatus in Yoruba apart from deletion and assimilation discussed by Orie \& Pulleyblank (2002). Thus, I identify fusion forms like ìgbékúgbè (< ìgbé.kí.ìgbé) as different from deletion forms like ilékílé (< ilé.kí.ilé) in Yorùbá. While NO HIATUS and MAX-IO are used for the analysis of deletion to resolve hiatus in reduplication, NO HIATUS and UNIFORMITY are used to analyze fusion as a way of resolving hiatus in reduplication. Essentially, in each case, the ranking of constraints is crucial in 
determing the optimal candidate.

Third, I observe different constraints ranking in reduplication where IDENT BR is high ranked in reduplication forms including deletion, but low ranked in reduplication forms including fusion, to produce the right output. Thus, for reduplication in OT, different constraints ranking may be triggered by other processes occurring within the reduplication itself. Using a single constraint ranking may be complicated since constraints ranking has to account for both the reduplication and other phonological processes that might be involved.

\section{References}

Abakah, E. 2015. On Tone and Morphophonology of the Akan Reduplication Construction. Journal of Universal Language 16.1, $1-47$.

Akinlabi, A. \& F. Oyebade. 1987. Lexical and Post-lexical Rule Application: Vowel Deletion in Yoruba. Journal of West African Languages 17, 23-42.

Awoyale, Y. 1985. Vowel Assimilation and Elision in Yoruba: The Interface of Phonology and Syntax. Paper presented at the 6th Annual Conference of the Linguistic Association of Nigeria. Ahmadu Bello University, Zaria.

Awoyale, Y. 1991. İtẹèsíwájú Lórí ìhun Gbólóhùn Èdè Yorùbá: Àlàyé lórí Àpólà Ọòrọò Àpọónlé àti İsẹèdá Ọòrọo-orúkọ. Yorùbá Gbòde 1.7, 16-40.

Haspelmath, M \& A. Sims. 2010. Understanding Morphology. London: Hodder Education.

Hyman, L., S. Inkelas \& G. Sibanda. 2009. Morphosyntactic 
Correspondence in Bantu Reduplication. In K. Hanson \& S. Inkelas (eds.), The Nature of the Word: Essays in Honor of Paul Kiparsky 273-310. Cambridge, MA: MIT Press.

Inkelas, S. \& C. Zoll. 2005. Reduplication: Doubling in Morphology. Cambridge: CUP.

Kager, R. 2004. Optimality Theory. Cambridge: CUP.

McCarthy, J. \& A. Prince. 1995. Faithfulness and Reduplicative Identity. In J. Beckman, L. Dickey \& S. Urbanczyk (eds.), UMPO 18: Papers in Optimality Theory 249-384. Amherst, MA: GLSA.

Ola, O. 1991. Vowel Deletion in Yoruba Verb-Noun Collocation Revisited. Research in African Languages \& Literatures 1, 95-98. Orie, O. \& D. Pulleyblank. 2002. Yoruba Vowel Elision: Minimality Effects. Natural Language \& Linguistic Theory 20, 101-156.

Owolabi, K. 1995. More on Yorùbá Prefixing Morphology. In K. Owolabi (ed.), Language in Nigeria: Essays in Honour of Ayo Bamgbose 92-112. Ibadan: Group Publishers.

Pulleyblank, D. 1988. Vowel Deletion in Yoruba. Journal of African Languages \& Linguistics 10, 117-136.

Pulleyblank, D. 2009. Patterns of Reduplication in Yoruba. In K. Hanson \& S. Inkelas. (eds.), The Nature of the Word: Essays in Honor of Paul Kiparsky 311-357. Cambridge, MA: MIT Press.

Taiwo, O. 2013. Morphology Syntax Interaction in the Derivation of Nominal Compounds in Yorùbá. Studi Linguistici e Filologici Online 10, 1-46.

Tak, J-Y. 2007. Three Cross-Linguistic Tendencies in Reduplication Revised. Journal of Universal Language 8.1, 105-122. 